\title{
Studi Kualitatif dalam Kajian Stres Akademik
}

\author{
ADISMARA PUTRI PRADIRI*, ENDANG RETNO SURYANINGRUM, \& WIWIN HENDRIANI \\ Fakultas Psikologi, Universitas Airlangga
}

\begin{abstract}
ABSTRAK
Studi ini merupakan narrative review mengenai temuan dari penelitian kualitatif yang mengkaji stres akademik. Penelitian kualitatif memiliki keunggulan dibanding penelitian kuantitatif untuk menggali kedalaman data seperti stressor dan cara coping yang tepat untuk permasalahan yang dihadapi, namun masih sedikit kajian stres akademik dari segi kualitatif. Hasil narrative review menunjukkan stressor apa saja yang dihadapi oleh mahasiswa pada konteks bervariasi serta strategi coping yang tepat. Ini mendukung perlunya penelitian kualitatif pada kajian stres sebagai penggalian data terhadap persepsi individu terkait stres itu sendiri. Meskipun demikian kelemahan kualitatif saat ini menjadikannya metode penelitian ini sebagai komplementer dari kuantitatif.
\end{abstract}

Kata kunci: kualitatif, stres akademik, stressor akademik, strategi coping, mahasiswa

\begin{abstract}
This study is a narrative review about the findings of qualitative study towards academic stress. Qualitative study excels in collecting the in-depth data such as the variety of stressors and coping strategies. Result shows what kind of stressors become the challenge of the students in various context. It is also followed by which coping strategy is suitable with certain stressors. This supports the argument to utilize qualitative study in stress research to get insight on how an individual perceive stress itself. However, the drawback of qualitative study limits to be the complimentary method of quantitative as for now.
\end{abstract}

Keywords: qualitative, academic stress, academic stressor, coping strategy, students

INSAN Jurnal Psikologi dan Kesehatan Mental, 2021, Vol. 6(2), 79- 89, doi: 10.20473/jpkm.v6i22021.79-89 Dikirimkan: 2 November 2020 Diterima: 28 November 2021 Diterbitkan: 1 Desember 2021 Editor: Rizqy Amelia Zein

*Alamat korespondensi: Fakultas Psikologi Universitas Airlangga, Kampus B Universitas Airlangga Jalan Airlangga 4-6 Surabaya 60286. Pos-el: adismara.putri.pradiri-2020@psikologi.unair.ac.id

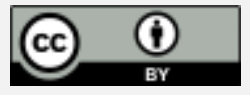

Naskah ini merupakan naskah dengan akses terbuka dibawah ketentuan the Creative Common Attribution License (http://creativecommons.org/licenses/by/4.0), sehingga penggunaan, distribusi, reproduksi dalam media apapun atas artikel ini tidak dibatasi, selama sumber aslinya disitir dengan baik. 


\section{PEN D A H U L U A N}

Stres akademik menjadi salah satu topik yang tidak dapat dilepaskan dari dunia pendidikan, khususnya stress akademik yang diderita oleh mahasiswa. Stres akademik merupakan keadaan individu yang mengalami terlalu banyak tekanan dan tuntutan sehingga tidak dapat mengelola tugas akademik dengan baik (Ibrahim, Kelly, Adams, \& Glazebrook, 2013). Lingkungan baru serta gaya pembelajaran yang berbeda dari masa sekolah memaksa mahasiswa untuk beradaptasi dengan tuntutan yang ada sehingga memicu munculnya gejala-gejala stres (Hou, Linping, Liu, \& Yaozhong, 2016). Stres akademik terkadang juga berakar dari tuntutan non-akademik tetapi masih dalam lingkup perannya sebagai mahasiswa, seperti masalah finansial pada mahasiswa perantau, permasalahan interpersonal, gangguan intrapersonal, ketidaksiapan memulai kehidupan sebagai mahasiswa, dan ketidakseimbangan kehidupan akademik dan pribadi (Nelson \& Low, 2011; Lewin \& Mawoyo, 2014; Van Zyl, 2016). Ketidakmampuan mahasiswa untuk mengatasi permasalahan ini dengan sistem coping yang tidak efektif menyebabkan munculnya stres akademik (Bataineh, 2013). Hal ini ditambah dengan kurangnya sumberdaya dalam membantu mereka mempersepsikan stres sebagai sesuatu yang sangat negatif (Kausar, 2010).

Dampak yang muncul akibat stres akademik dapat mempengaruhi performa akademik dan kesejahteraan mental. Studi literatur yang dilakukan oleh Shkulaku (2015) menunjukkan dampak stres akademik dapat mempengaruhi performa akademik, seperti kelelahan emosional, mengurangi efektivitas mengerjakan tugas, abstenteisme, hingga menyebabkan ganggua kesehatan seperti hipertensi. Frazier, Gabriel, Merians dan Lust (2018) juga menemukan bahwa stres akademik menjadi faktor nomor satu yang menghambat dan menyulitkan performa akademik mahasiswa. Studi tersebut juga menunjukkan bahwa mahasiswa yang menganggap stres sangat mengganggu performa akademik memiliki karakteristik self-efficacy yang rendah dan kurangnya dukungan dari keluarga maupun teman dibanding mahasiswa yang tidak terpengaruh dengan stres.

Kajian-kajian yang bersifat eksploratif sangat terbuka lebar untuk menggali stres akademik dari berbagai perspektif. Beberapa studi yang menggunakan metode kuantitatif bisa mengukur secara empiris mengenai tingkat stres akademik mahasiswa melalui skala-skala psikometrik, tetapi cara ini dikritik karena dianggap mengabaikan kekhasan stressor dari perspektif individu tersebut. Penelitian dengan kualitatif lebih eksploratif karena bisa memberikan temuan baru seperti apa stressor yang paling berpengaruh, tantangan untuk menghadapi stressor, termasuk perilaku coping yang khas dan tidak persis sama dengan instrumen psikometri yang tersedia (Mazolla, Schonfeld, \& Spector, 2011). Polapola tersebut khususnya berkaitan dengan latar belakang budaya dan ekspektasi sosial (Lee, dkk., 2005). Mazolla dkk. (2011) tidak mendeklarasikan bahwa penelitian kualitatif adalah penelitian yang tanpa kekurangan, namun penelitian kualitatif dapat menyediakan bukti pelengkap dari temuantemuan penelitian kuantitatif karena sanggup memberikan kedalaman dari sebuah topik kajian.

Lee, Kang, \& Yum (2005) juga menyatakan bahwa penelitian kualitatif bisa membantu menemukan pola-pola coping yang bersifat personal dan efektif dengan pemaknaan individu terhadap stressor khas yang dihadapi. Hal ini tampak dari kajian kualitatif terkait stres yang berkaitan dengan partisipan tertentu seperti stressor dan pola coping remaja dalam konteks keluarga militer (Bradshaw, Sudhinaraset, Mmari, \& Blum, 2010), persepsi mendalam stres profesi mahasiswa praktik kedokteran (Radcliffe \& Lester, 2003), hingga tenaga medis (Reid dkk., 1999). Tujuan dari penelitian kualitatif dalam ranah stres juga umumnya bisa membantu menggali lebih dalam yang tidak dapat dijelaskan melalui pertanyaan tertutup (closed-questioning) seperti bagaimana partisipan memanjang stressor-stressor tersebut sehingga dapat merumuskan tindakan yang perlu dilakukan oleh institusi seperti sekolah untuk mengatasi stres tersebut (Radcliffe \& Lester, 2003). 
Penelitian ini akan mencoba untuk mengulas secara naratif mengenai temuan kajian metode kualitatif pada 10 tahun terakhir. Hal ini didasari oleh dorongan Lembaga Ilmu Pengetahuan Indonesia untuk membatasi rujukan pustaka yang baik adalah dalam rentang 10 tahun terakhir dikarenakan perubahan informasi yang cepat dan pembahasan yang lebih mendalam (Wilis, 2013). Studi ini tidak membatasi pada temuan berupa stressor saja, namun membuka pintu bagi temuan-temuan lain yang bersifat kualitatif seperti tingkat stres yang digambarkan secara kualitatif hingga gejala-gejala manifestasi dari stres akademik. Tujuan dari analisis narrative review ini adalah untuk membagikan temuan baru yang dapat memberikan wawasan bagi calon peneliti kualitatif dalam menggali topik stres akademik.

\section{E T ODE}

\section{Narrative review}

Penelitian ini menggunakan metode narrative review yang digunakan untuk mendeskripsikan suatu literatur secara umum dan tidak sekaku systematic review (Kartika, Suminar, Tairas, \& Hendriani, 2018). Salah satu keunggulan dari narrative review adalah menggabungkan berbagai informasi yang bermanfaat terkait suatu topik menjadi sebuah artikel yang mudah dibaca dan dipahami. Tujuan dari narrative review adalah menyajikan sebuah perkembangan dari kajian tertentu dan tidak mengharuskan peneliti untuk memberikan kritik karena sifatnya hanya mengkondensasikan informasi yang tersedia. Tidak jarang jika narrative review lebih dipilih oleh akademisi daripada buku teks karena lebih terbaru dan bisa menjadi sumber tunggal utama mahasiswa dalam mempelajari suatu kajian (Green, Johnson, \& Adams, 2006).

\section{Pengambilan data dan seleksi}

Penulis melakukan sejumlah pengumpulan jurnal dari basis data Google Scholar, Science Direct, dan Proquest yang berisi artikel dengan topik yang bervariasi. Kata kunci yang digunakan adalah "stres akademik" dan "academic stress". Artikel yang dibatasi untuk topik kajian ini yaitu dalam rentang waktu tahun 2010 hingga 2020. Artikel yang diambil menjadi sampel adalah temuan penelitian yang dilakukan di Indonesia atau di negara lain, selama artikel ditulis dalam Bahasa Indonesia atau Bahasa Inggris. Pertimbangan pembatasan waktu artikel ini adalah karena stres akademik menjadi kajian yang selalu ada dan diperbarui sehingga rentang waktu 10 tahun adalah rentang referensi artikel yang paling direkomendasikan.

Artikel yang diambil menjadi sampel adalah artikel-artikel yang menggunakan metode kualitatif karena sesuai dengan tujuan penelitian kali ini yaitu mengulas temuan-temuan yang berasal dari metode kualitatif dalam mengkaji stres akademik. Penelitian berbasis mixed method dan systematic review dieksklusikan karena tidak fokus pada temuan metode kualitatifnya. Penelitian stres akademik pada siswa sekolah non mahasiswa juga tidak masuk dalam kriteria seleksi. Proses pencarian dan seleksi artikel digambarkan melalui diagram alir di Gambar 1.

Seleksi artikel memberikan hasil yaitu tujuh artikel dari tahun 2010 hingga 2020 dengan dua aspek, yaitu strategi coping menghadapi stres akademik dan stressor akademik itu sendiri. Kedua aspek ini merupakan kajian utama dari artikel-artikel tersebut yang dibahas melalui metode penelitian data kualitatif. Kedua aspek akan selanjutnya dibahas dalam dua subtopik, yang berikutnya akan diuraikan pada bagian hasil penelitian. Ulasan singkat mengenai artikel penelitian yang terpilih menjadi sampel dapat dilihat di Tabel 1. 


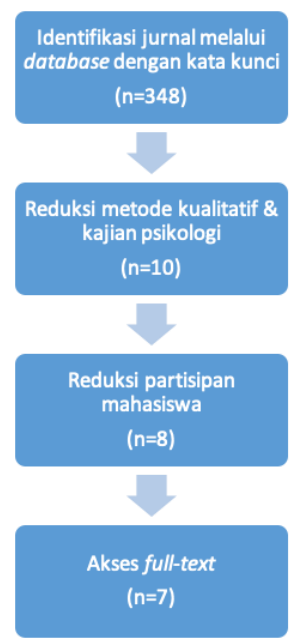

Gambar 1. Diagram Alir Pencarian dan Seleksi Artikel

Tabel 1. Artikel Hasil Seleksi untuk Narrative Review

\begin{tabular}{|c|c|c|c|c|}
\hline No. & Peneliti & Tahun & Aspek & Responden \\
\hline 1. & Zuama & 2014 & $\begin{array}{l}\text { Strategi coping } \\
\text { menghadapi stres } \\
\text { akademik }\end{array}$ & $\begin{array}{l}\text { Mahasiswa PG PAUD } \\
\text { yang menyusun } \\
\text { skripsi }\end{array}$ \\
\hline 2. & $\begin{array}{l}\text { Hjeltnes, Binder, Moltu, \& } \\
\text { Dundas }\end{array}$ & 2015 & $\begin{array}{l}\text { Strategi coping } \\
\text { menghadapi stres } \\
\text { akademik }\end{array}$ & $\begin{array}{l}\text { Mahasiswa berbagai } \\
\text { jurusan }\end{array}$ \\
\hline 3. & Mason & 2017 & $\begin{array}{l}\text { Strategi coping } \\
\text { menghadapi stres } \\
\text { akademik }\end{array}$ & $\begin{array}{l}\text { Mahasiswa tahun } \\
\text { pertama }\end{array}$ \\
\hline \multirow[t]{2}{*}{4.} & \multirow[t]{2}{*}{ Dahan \& Bedos } & \multirow[t]{2}{*}{2010} & $\begin{array}{l}\text { Strategi coping } \\
\text { menghadapi stres } \\
\text { akademik }\end{array}$ & \multirow[t]{2}{*}{$\begin{array}{l}\text { Lulusan mahasiswa } \\
\text { kedokteran gigi }\end{array}$} \\
\hline & & & Stressor akademik & \\
\hline 5. & Khawaja \& Stallman & 2011 & Stressor akademik & $\begin{array}{l}\text { Mahasiswa } \\
\text { internasional }\end{array}$ \\
\hline 6. & $\begin{array}{l}\text { Weber, Skodda, Muth, } \\
\text { Angerer, \& Loerbroks }\end{array}$ & 2019 & Stressor akademik & $\begin{array}{l}\text { Mahasiswa } \\
\text { kedokteran }\end{array}$ \\
\hline 7. & Xie, Yaqoob, Mansell, \& Tai & 2019 & Stressor akademik & $\begin{array}{l}\text { Mahasiswa arsitektur } \\
\text { (S1 \& S2) }\end{array}$ \\
\hline
\end{tabular}




\section{HAS I L P E N EL I T I A N}

\section{Stressor akademik}

Studi yang dilakukan oleh Dahan dan Bedos (2010) berupaya untuk mengklasifikasikann mahasiswa kedokteran gigi dalam berbagai kategori berdasarkan beberapa aspek, seperti stressor dan strategi coping. Metode yang dilakukan adalah wawancara tatap muka secara semistruktural dan fokus pada ekplorasi persepsi pengalaman stres yang dialami oleh para mahasiswa. Tujuan eksplorasi ini adalah mengidentifikasi stressor utama, manifestasi stres, dan strategi coping mahasiswa. Hasil dari wawancara akan ditranskrip kemudian dibagi menjadi beberapa tema dan kategori untuk menjawab pertanyaan what, why, where, who, when, dan why (5W1H). Dahan dan Bedos (2010) membagi mahasiswa menjadi tiga kategori utama, yaitu highly stressed, moderately stressed, dan relaxed.

Mahasiswa dalam kategori highly stressed atau tingkat stres tinggi mengaku bahwa mereka adalah mahasiswa yang kesulitan untuk mengikuti pembelajaran dan perfeksionis. Mahasiswa yang kesulitan mengikuti pembelajaran menganggap bahwa pengalaman belajar mereka membuat mereka stres dan dipersepsikan secara negatif. Di sisi lain, mahasiswa perfeksionis mengaku bahwa mereka memang mendapatkan hasil yang bagus tetapi selalu menanggapinya secara kritis dan beranggapan bahwa mereka seharusnya bisa lebih baik dari hal ini. Sumber stres pada mahasiswa highly stressed adalah ketakutan untuk gagal, beban kerja berlebihan, masa transisi ke jenjang yang lebih tinggi, dan masalah dengan staf akademik (khusus mahasiswa yang kesulitan dalam pembelajaran) (Dahan \& Bedos, 2010).

Mahasiswa yang masuk dalam kategori moderately stressed mengaku bahwa pendidikan kedokteran gigi memang melelahkan tetapi mereka bisa mengelolanya jika fokus pada belajar dan mempersiapkan praktik. Stres yang dialami justru menjadi sebuah motivasi untuk belajar. Mereka menggambarkan diri mereka sebagai mahasiswa yang biasa saja dan rata-rata. Sumber stressor mereka adalah beban pekerjaan serta masa transisi yang kerap membuat cemas. Sedangkan mahasiswa yang relaxed justru mengaku sebagai mahasiswa yang berada di atas rata-rata. Mereka beranggapan bahwa beban kerja memang membuat mereka stres tetapi tidak mempengaruhi hidup mereka (Dahan \& Bedos, 2010).

Faktor di atas juga muncul pada studi yang dilakukan oleh Weber, dkk. (2019). Studi tersebut menunjukkan hasil yang lebih beragam dari 68 mahasiswa kedokteran. Metode pengambilan data dilakukan melalui pendekatan di media sosial kemudian pembentukan focus group discussion (FGD) untuk memfasilitasi diskusi terbuka. Data transkrip menunjukkan dua kategori utama yaitu stressor dan resource. Pada kategori stressor, Weber, dkk. (2019) menampilkan adanya tujuh stressor akademik pada mahasiswa yaitu organisasi, pengajar, ujian, performa dan tekanan waktu, konflik sosial, internal diri sendiri, dan masalah lain.

Stressor organisasi berkaitan dengan regulasi yang ada pada institusi tersebut, seperti informasi yang kurang jelas, jadwal kuliah, kurikulum yang belum terstruktur, acara yang tiba-tiba dibatalkan, hingga konversi transisi menuju kurikulum baru. Stressor ujian berkisar pada level kesulitan yang tinggi, kurang persiapan, jumlah ujian terlalu banyak dan kumulatif, kurangnya hasil yang tidak sesuai dengan usaha, hingga ujian berulang. Stressor pengajar yaitu kurangnya kualitas pengajar, konten pembelajaran, dan pelatihan. Stressor performa terdiri dari situasi kompetitif, perlunya pengaturan jadwal ulang untuk diri sendiri dan beban yang terlalu berat (Weber, dkk., 2019).

Tidak hanya berkaitan dengan pembelajaran stressor seperti lingkungan sosial pun juga berkontribusi pada stres akademik. Interaksi dengan staf akademik, mahasiswa, dan guru juga kerap menjadi stressor. Selain itu, stressor internal seperti rasa bersalah, ekspektasi diri terlalu tinggi, kesulitan untuk rileks, hingga ketakutan untuk gagal juga menghantui mahasiswa. Terakhir adalah stressor lain, yaitu kondisi finansial, perjalanan ke kampus, transisi dan adaptasi dari SMA ke universitas, ketidaksiapan untuk menuju dunia kerja, dan juga ujian thesis menjadi masalah lainnya (Weber, dkk., 2019).

INSAN Jurnal Psikologi dan Kesehatan Mental

2021, Vol. 6(2), 79-89

doi: 10.20473/jpkm.v6i22021.79-89 
Temuan yang sama muncul pada penelitian Xie, dkk. (2019) melalui metode cross-sectional. Pemilihan partisipan dilakukan lewat purposive sampling dan pengambilan data dilakukan melalui wawancara individual semi-structured dengan pertanyaan open-ended yang mengajak partisipan untuk mendiskusikan kegiatan dan pengalamannya dalam menjalani perkuliahan. Pedoman topik sudah disiapkan sebelumnya melalui diskusi antara peneliti dengan salah seorang mahasiswa non-partisipan.

Stressor dibagi menjadi lima kategori yaitu beban tugas, budaya bekerja keras, tingkat kreativitas subjektif, kritik dari tutor, dan masalah spesifik pada semester tertentu. Partisipan mengaku bahwa beban tugas dibagi menjadi ceramah dosen di kelas dan praktik di studio. Praktik inilah yang memberikan beban paling banyak bagi para mahasiswa karena adanya praktik rutin yang mengharuskan mereka untuk mengaplikasikan semua materi dalam satu hari. Sedangkan budaya bekerja keras menjadi stressor karena budaya tersebut sangat kental bahkan menjadi sebuah prinsip sejak awal masuk kuliah. Banyak senior yang mempersuasi partisipan untuk terus bekerja keras sampai merasa bersalah jika tidak ikut bekerja (Xie, dkk., 2019).

Stressor ketiga, yaitu tingkat kreativitas, sangat berkaitan dengan kemampuan partisipan untuk mempraktikkan ilmunya, yaitu arsitektur. Banyak yang mempersepsikan 'kebebasan berkreasi' sebagai ketakutan karena tidak tahu benar dan salahnya. Belum lagi jika selera partisipan dinilai buruk. Ini berkaitan dengan stressor selanjutnya yaitu kritik dari tutor yang dianggap keras namun harus 'ditelan' setiap hari. Partisipan menganggap tutor tidak pernah bisa merasa puas. Stressor terakhir adalah masalah spesifik pada semester tertentu yaitu pada semester 1-2 dan 5-6. Mahasiswa baru cenderung kesulitan untuk belajar karena dirasa tidak memiliki dasar yang kuat sehingga merasa tersesat. Sedangkan mahasiswa semester atas menganggap bahwa semester 5-6 sangat sulit dan stres muncul secara konstan karena terbebani nilai bagus agar bisa mendapatkan pekerjaan yang sesuai (Xie, dkk., 2019).

Khawaja dan Stallman (2011) melakukan studi kualitatif pada mahasiswa internasional tentang bagaimana mereka mempersepsikan stressor. Metode dilakukan dengan mewawancarai 22 mahasiswa internasional dengan FGD dengan dua topik pertanyaan utama, yaitu kesulitan berkuliah sebagai mahasiswa internasional dan membagikan pengalaman mereka dalam mengelola stres serta memberikan nasehat kepada teman lainnya untuk membantu mengelola stres.

Pada stressor pertama yaitu penyesuaian diri, partisipan setuju bahwa kemampuan hidup mandiri menjadi sangat penting seperti kemampuan memasak. Selain itu, partisipan juga menghubungi keluarga lebih sering menjadi cara untuk menenangkan diri khususnya mengatasi homesick. Stressor kedua, yaitu isolasi sosial dan kesepian, partisipan merasa kesulitan untuk memulai sebuah pertemanan, tetapi membangun pertemanan ternyata membantu mereka untuk menghilangkan kesepian. Beberapa partisipan merasa nyaman berteman dengan teman dari negara yang sama, sedangkan beberapa memilih dengan mahasiswa lokal. Membaca koran dan juga mencari teman yang memiliki hobi samalebih membantu daripada memaksakan diri untuk mencari teman dari nol (Khawaja \& Stallman, 2011).

Kendala selanjutnya adalah Bahasa Inggris, karena tidak semua partisipan memahami aksen Australia sehingga berpengaruh pada studi mereka. Begitu pula ketakutan bahwa orang lain tidak memahami aksen partisipan yang bervariasi. Pada kendala pembelajaran sendiri partisipan masih perlu waktu untuk memahami jenis ujian yang ada di Australia seperti esai dan juga kerja kelompok. Cara interaksi partisipan dengan tutor dan dosen yang berbeda dengan negara asal mereka juga menjadi kendala dalam pembelajaran yang menjadi stressor akademik (Khawaja \& Stallman, 2011).

Kendala seperti ekspektasi yang tidak sesuai menjadi stressor yang kerap muncul karena banyaknya ketidaksesuaian dengan harapan yang mereka inginkan sejak awal khususnya dalam kasus interaksi sosial. Stressor ini yang paling sering menyebabkan kendala psikologis bagi para partisipan dengan

INSAN Jurnal Psikologi dan Kesehatan Mental

2021, Vol. 6(2), 79-89

doi: 10.20473/jpkm.v6i22021.79-89

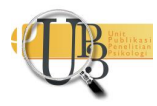


manifestasi seperti kecemasan dan depresi. Self-esteem yang menurun serta kepercayaan diri sangat menurun (Khawaja \& Stallman, 2011).

\section{Strategi coping menghadapi stres akademik}

Zuama (2014) mengkaji strategi coping mahasiswa dalam menghadapi stres akademik melalui metode deskriptif kualitatif selama satu tahun pada enam partisipan. Hasil tersebut digambarkan dalam empat strategi berbeda. Strategi pertama adalah dengan bekerja di tempat lain untuk mengalihkan perasaan tertekan serta menangis untuk melepaskan beban. Strategi kedua adalah dengan bercerita kepada sahabat atau orang yang dipercaya dan butuh untuk dimotivasi. Strategi kedua ini sangat mengandalkan dukungan dan afirmasi positif serta keterbukaan diri untuk bercerita. Strategi ketiga adalah dengan cara mengambil waktu istirahat sendiri, seperti mendengarkan musik, olahraga, dan berbagai aktivitas spontan yang menyenangkan. Sedangkan strategi keempat adalah memberikan waktu dengan kegiatan yang biasa dilakukan sebelumnya.

Hjeltnes, dkk. (2015) mengkaji bagaimana pengalaman mahasiswa mengaplikasikan mindfulness-based stress reduction (MBSR) untuk mengatasi stres dan kecemasan akademik. Metode yang digunakan adalah analisis tematik yang bertujuan untuk mengeksplorasi fenomenologi partisipan, pemaknaan yang muncul antara partisipan dan pewawancara, serta mengembangkan pengetahuan dari interpretasi deskripsi partisipan. MBSR dilakukan selama delapan minggu dan partisipan yang berkenan untuk wawancara adalah sebanyak 29 mahasiswa. Proses pengambilan data dilakukan dengan wawancara semi-struktur secara individual satu bulan setelah pelatihan MBSR. Hasilnya adalah lima tema utama yaitu; 1) menemukan sumber ketenangan, 2) berbagi perjuangan yang sama, 3) tetap fokus pada proses pembelajaran, 4) pergeseran kecemasan menjadi rasa ingin tahu, dan 5) penerimaan diri sendiri.

Pada tema pertama, hampir semua partisipan setuju bahwa awalnya praktek MBSR seperti meditasi sangat sulit karena semua partisipan memiliki masalah dengan kecemasan, frustrasi, dan ketakutan untuk gagal. Praktek secara terus menerus mulai membantu mereka untuk meregulasi pikiran negatif dan merasa bahwa MBSR menjadi langkah mundur untuk melihat dari perspektif lain. Beberapa partisipan mulai menggunakan teknik MBSR untuk mengatasi kecemasan dan juga membangun emosi ketenangan dengan teknik pernafasan. Tema kedua yaitu berbagi perjuangan yang sama benar-benar membantu mereka agar tidak kesepian. Partisipan menyatakan bahwa stres akademik kerap membuat mereka merasa kesepian karena terus diterpa oleh kritik diri sendiri. Ketika mendengarkan bahwa ternyata banyak yang merasakan kendala serupa, partisipan menjadi lebih lega dan menganggap bahwa stres dan kecemasan adalah respon wajar (Hjeltnes, dkk., 2015).

Pada tema ketiga, partisipan sepakat bahwa MBSR bisa membuat mereka mulai fokus pada situasi yang sebelumnya membuat cemas seperti persiapan ujian. Perubahan ini membantu mereka untuk mengurangi tingkat stres. Salah satu partisipan mengaku bahwa menerima sebuah distraksi justru meningkatkan konsentrasi. Tema keempat, yaitu pergeseran kecemasan menjadi ingin tahu berkisar pada bagaimana partisipan menjelaskan bahwa stres dan kecemasan muncul dari ketakutan untuk gagal. Namun MBSR membantu mengubah cara berpikir tersebut menjadi rasa iingin tahu untuk belajar lebih giat dan mendalami topik pembelajaran. Pada tema terakhir partisipan merasakan bahwa menerima diri sendiri membantu mereka lebih baik bahkan pada situasi yang sulit. Jika sebelumnya partisipan dipenuhi dengan perasaan "harus lolos" atau "seharusnya kamu bisa", maka setelah mengikuti pelatihan MBSR partisipan justru merasa mereka lebih lega dan menerima semua hasil tanpa harus melebih-lebihkan ketakutan tersebut (Hjeltnes, dkk., 2015).

Mason (2017) melakukan riset kualitatif secara naratif untuk mendeskripsikan pengalaman partisipan untuk menghadapi stressor akademik dan bagaimana strategi coping tersebut bisa berpengaruh untuk

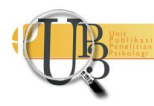


mendapatkan keseimbangan kehidupan akademik. Metode pengambilan data dilakukan dengan nä̈ve sketches atau pemaknaan partisipan tentang suatu tema melalui dokumen yang mereka ciptakan. Langkah pertama yaitu penulisan pengalaman, kemudian partisipan diminta untuk menggambar sesuatu yang mewakili proses coping mereka. Langkah terakhir adalah partisipan diminta menulis essay tentang gambar tersebut dan menjelaskan apa makna dari gambar tersebut. Muncul tiga strategi coping utama yaitu problem-focused, emotion-focused, dan meaning-making.

Problem-focused berarti partisipan mencoba untuk memahami masalah yang terjadi dan mencari solusi terbaik. Emotion-focused yaitu partisipan fokus pada pengelolaan emosi, seperti mencoba melakukan hal-hal yang disukai seperti berjalan-jalan atau menonton film. Adapun meaning-making adalah strategi untuk memaknai semua masalah yang muncul seperti melalui pendekatan spiritual yang meyakini ada makna di balik semua permasalahan, misalnya menguatkan diri sendiri (Mason, 2017).

Dahan dan Bedos (2010) juga menjelaskan bagaimana strategi coping berbeda pada tingkat stres yang berbeda. Partisipan dengan tingkat highly stressed justru cenderung menunjukkan strategi maladaptif seperti menghindari stressor, cemas, dan berharap pada sesuatu yang tidak bisa dikontrol. Sedangkan pada partisipan moderate stressed, masih ada jejak strategi maladaptif tetapi juga dikombinasikan dengan strategi adaptif seperti mengikuti ekstrakurikuler, mencari dukungan, dan pengelolaan diri. Pada mahasiswa relaxed justru ditemukan bahwa strategi menghadapi stres atau kendala akademik adalah dengan strategi adaptif.

\section{I S K U S I}

Studi kualitatif mengenai stres akademik umumnya menggali dua permasalahan utama yaitu jenis stressor dan bagaimana individu mengatasi stressor tersebut dengan strategi coping. Referensi berbeda tetap menunjukkan adanya kesamaan pola stressor akademik pada mahasiswa. Namun pemaknaan dari masing-masing stressor tersebut bisa saling berbeda. Xie, dkk. (2019) yang menjelaskan bahwa stressor seperti beban akademis muncul dan dimaknai sebagai sebuah tekanan karena partisipan harus mempelajari banyak hal dalam satu waktu dan mempraktikkannya, sedangkan Khawaja dan Stallman (2011) menunjukkan beban akademis dimaknai berbeda sebagai sebuah permasalahan karena berakar pada bahasa yang kurang dipahami serta perbedaan jenis tugas di budaya masing-masing partisipan.

Strategi coping juga bisa bervariasi dari masing-masing latar belakang partisipan. Pemaknaan bahwa satu partisipan lebih memilih bercerita kepada teman sedangkan partisipan lain lebih memilih beraktivitas sendirian menunjukkan adanya proses individual yang berbeda dalam merespon sebuah stressor. Metode kualitatif berhasil menangkap kekayaan data persepsi ini sesuai dengan pernyataan Mazzola, dkk. (2011) bahwa metode kualitatif pada kajian stres akademik bisa menggambarkan pola coping yang lebih bervariasi daripada mengacu pada skala atau instrumen kuantitatif saja.

Narrative review juga menunjukkan hasil yang sesuai dengan pernyataan Mazzola, dkk. (2011) tentang pertanyaan open-ended menjadi sebuah kekuatan penting. Kecuali Mason (2017), seluruh studi pada narrative review ini menggunakan pertanyaan open-ended yang memberikan data bervariasi untuk dikoding sesuai dengan tema agar menjadi lebih bermakna. Studi yang dilakukan oleh Mazzola, dkk. (2011) juga menyatakan bahwa penelitian kualitatif tidak bisa berdiri sendiri, dan lebih cocok jika dikombinasikan sebagai pendalaman dari penelitian kuantitatif. Penelitian kuantitatif sendiri cenderung dangkal namun mudah untuk dianalisis serta memiliki kualitas inter-rater yang lebih baik sehingga lebih reliabel. 


\section{S I M P U L A N}

Kajian stres akademik melalui metode kualitatif berhasil menjabarkan apa saja stressor akademik yang dihadapi serta stressor mana yang menjadi momok utama. Hal ini membantu peneliti untuk menggali lebih dalam terkait stressor akademik pada partisipan dengan latar belakang yang beragam. Kajian stres akademik melalui metode kualitatif juga berhasil menjelaskan bagaimana strategi coping yang berbeda bisa diterapkan untuk karakteristik individu berbeda serta stressor berbeda. Kekuatan studi ini didasari oleh open-ended question yang dapat menggali data secara mendalam hingga pemaknaan individu terkait stressor dan strategi coping itu sendiri yang bervariasi. Peneliti di masa depan diharapkan bisa menggali data-data terkait stressor dan coping stres akademik pada berbagai kalangan mahasiswa sehingga dapat memetakan faktor protektif dan faktor resiko pada masing-masing partisipan.

Keterbatasan dalam penelitian kualitatif adalah kurangnya reliabilitas dalam publikasi jurnal yang mengandalkan inter-rater. Penelitian kualitatif juga masih dianggap sebagai komplementer dari penelitian kuantitatif yang lebih mudah untuk dilakukan. Studi narrative review ini menunjukkan bahwa penelitian kualitatif bisa menjabarkan dengan lebih mendalam melalui open-ended question dan diharapkan bisa menjadi fondasi pengembangan instrumen ataupun kajian studi, seperti fokus pada stressor paling umum atau cara coping yang paling menguntungkan sehingga bisa menjadi fondasi perancangan strategi penanganan stres akademik mahasiswa.

\section{DEKLARASI POTENSI TERJADINYA KONFLIK KEPENTINGAN}

Adismara Putri Pradiri, Endang Retno Suryaningrum, dan Wiwin Hendriani tidak bekerja, menjadi konsultan, memiliki saham, atau menerima dana dari perusahaan atau organisasi manapun yang mungkin akan mengambil untung dari diterbitkannya naskah ini.

\section{PUSTAKA ACUAN}

Bataineh, M. Z. (2013). Academic stress among undergraduate students: the case of education faculty at King Saud University. International interdisciplinary journal of education, 1(1033), 1-7. https://doi.org/10.12816/0002919

Bradshaw, C. H., Sudhinaraset, M., Mmari, K., \& Blum, R. W. (2010). School transitions among military adolescents: A qualitative study of stress and coping. School Psychology Review, 39(1), 84-105. https://doi.org/10.1080/02796015.2010.12087792

Dahan, H., \& Bedos, C. (2010). A typology of dental students according to their experience of stress: A qualitative study. Journal of Dental Education, 95-103. https://doi.org/10.1002/j.00220337.2010.74.2.tb04858.x

Frazier, P., Gabriel, A., Merians, A., \& Lust, K. (2019). Understanding stress as an impediment to academic performance. Journal of American College Health, 67(6), 562-570. https://doi.org/10.1080/07448481.2018.1499649

Green, B. N., Johnson, C. D., \& Adams, A. (2006). Writing narrative literature reviews for peer-reviewed journals: secrets of the trade. Journal of Chiropractic Medicine, 5(3), 101-117. https://doi.org/10.1016/s0899-3467(07)60142-6

Hjeltnes, A., Binder, HAL. -E., Moltu, C., \& Dundas, I. (2015). Facing the fear of failure: An explorative qualitative study of client experiences in a mindfulness-based stress reduction program for university students with academic evaluation anxiety. International Journal of Qualitative Studies on Health and Well-being, 10(1), 1-14. https://doi.org/10.3402/qhw.v10.27990

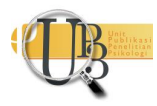


Hou, L., \& Liu, Y. (2016). The influence of stressful life events of college students on subjective wellbeing: The mediation effect of the operational effectiveness. Open Journal of Social Sciences, 4(06), 70. https://doi.org/10.4236/jss.2016.46008

Ibrahim, A. K., Kelly, S. J., Adams, C. E., \& Glazebrook, C. (2013). A systematic review of studies of depression prevalence in university students. Journal of psychiatric research, 47(3), 391-400. https://doi.org/10.1016/j.jpsychires.2012.11.015

Kartika, A., Suminar, D. R., Tairas, M. M., \& Hendriani, W. (2018). Individual education program (IEP) paperwork: A narrative review. International Journal of Engineering \& Technology, 7(2.29), 682.

Kausar, R. (2010). Perceived stress, academic workload, and use of coping strategies by university students. Journal of Behavioural Sciences, 20(1), 31-45.

Khawaja, N., \& Stallman, H. (2011). Understanding the coping strategies of international students: A qualitative approach. Journal of Psychologists and Counsellors in Schools, 21(2), 203-224. https://doi.org/10.1375/ajgc.21.2.203

Lee, D. H., Kang, S., \& Yum, S. (2005). A Qualitative Assessment of Personal and Academic Stressors among Korean College Students: An Exploratory Study. College Student Journal, 39(3).

Lewin, T., \& Mawoyo, M. (2014). Student access and success: Issues and interventions in South African universities. Cape Town: The South African Institute for Advancement.

Mason, H. D. (2017). Stress-management strategies among first-year students at a South African University: A qualitative study. Journal of Student Affairs in Africa, 5(2), 131-149. https://doi.org/10.24085/jsaa.v5i2.2744

Mazzola, J. J., Schonfeld, I. S., \& Spector, P. E. (2011). What qualitative research has taught us about occupational stress. Stress and Health, 27(2), 93-110. https://doi.org/10.1002/smi.1386

Nelson, D., \& Low, G. (2011). Emotional intelligence: Achieving academic and career excellence. New Jersey: Prentice Hall.

Radcliffe, C., \& Lester, H. (2003). Perceived stress during undergraduate medical training: a qualitative study. Medical education, 37(1), 32-38. https://doi.org/10.1046/j.1365-2923.2003.01405.X

Reid, Y., Johnson, S., Morant, N., Kuipers, E., Szmukler, G., Thornicroft, G., ... \& Prosser, D. (1999). Explanations for stress and satisfaction in mental health professionals: a qualitative study. Social psychiatry and psychiatric epidemiology, 34(6), 301-308. https://doi.org/10.1007/s001270050148

Shkulaku, R. (2015). Student's stress in higher education institutions: A critical review of foreign literatures and the ones in Albania. European Scientific Journal, 40-48.

Van Zyl, A. (2016). The contours of inequality: The links between socio-economic status of students and other variables at the University of Johannesburg. Journal for Students Affairs in Africa, 4(1), 116.

Wilis, J. (2011). Pola Rujukan Sumber Acuan pada Jurnal Penelitian Pertanian Terakreditasi. Jurnal Tanah dan Iklim, 34(7), 10-28.

Weber, J., Skodda, S., Muth, T., Angerer, P., \& Loerbroks, A. (2019). Stressors and resources related to academic studies and improvements suggested by medical students: a qualitative study. $B M C$ Medical Education, 19(1), 1-14. https://doi.org/10.1186/s12909-019-1747-z 
Xie, Y., Yaqoob, A., Mansell, W., \& Tai, S. (2021). A qualitative investigation of stress related to studying architecture at degree level in the UK. Arts and Humanities in Higher Education, 20(1), 3-20. https://doi.org/10.1177/1474022219871001

Zuama, S. N. (2014). Kemampuan mengelola stres akademik pada mahasiswa yang sedang skripsi angkatan 2009 program studi PG PAUD. Kreatif, 17(2). 